\title{
EXPLORING INDUCTIVE GRAMMAR TEACHING: ENGLISH TEACHER PERSPECTIVES
}

\author{
Didin Nuruddin Hidayat \\ Syarif Hidayatullah State Islamic University of Jakarta, Indonesia \\ (didin.nuruddin@uinjkt.ac.id)
}

Received: $8^{\text {th }}$ August 2017; Revised: $15^{\text {th }}$ September 2017; Accepted: $22^{\text {th }}$ December 2017

\begin{abstract}
In the past few decades, the discussion of what grammatical structures to teach, and especially how to teach them remains controversial (Boroujeni, 2012; Ellis, 2006). This research study aimed to explore the role of inductive grammar teaching toward specific grammatical structure, i.e. the second conditional or the unreal/hypothetical conditional. In light of this, ten English teachers were involved in this study, providing beneficial feedback through their experience in English language teaching. They were given two sessions of inductive grammar teaching, and were asked to engage with the lessons and provide feedback. The results showed that inductive grammar teaching possessed its strengths and weaknesses. One of the strengths was its ability in engaging more active participation from the students. However, a notable weakness was in terms of its lack of opportunities in explicit grammatical explanation.
\end{abstract}

Key Words: grammar; inductive approach; second conditional sentence

\section{ABSTRAK}

Dalam beberapa dekade terakhir, diskusi tentang struktur tata bahasa apa yang perlu diajarkan, dan teruatama bagaimana mengajarkan struktur tata bahasa tersebut tetap menjadi isu yang kontroversial (Boroujeni, 2012; Ellis, 2006). Penelitian ini bertujuan untuk mengeksplorasi peran pengajaran tata bahasa induktif terhadap struktur tata bahasa tertentu, yaitu the second conditional atau the unreal/hypothetical conditional. Untuk itu, sepuluh guru bahasa Inggris dilibatkan dalam penelitian ini, memberikan umpan balik yang bermanfaat melalui pengalaman mereka dalam bidang pengajaran bahasa Inggris. Mereka diberi dua sesi pengajaran tata bahasa induktif, dan diminta untuk terlibat dengan sesi-sesi tersebut dan juga memberikan umpan balik. Hasilnya menunjukkan bahwa pengajaran grammmar induktif memiliki kekuatan dan kelemahannya. Salah satu kekuatan berasal dari kemampuannya dalam melibatkan partisipasi yang lebih aktif dari para siswa. Namun, salah satu kelemahan yang menonjol adalah dalam hal kurangnya peluang dalam menjelaskan tata bahasa secara eksplisit.

Kata Kunci: grammar; pendekatan induktif; second conditional sentence

How to Cite: Hidayat, D.N. (2017). Exploring Inductive Grammar Teaching: English Teacher Perspectives. IJEE (Indonesian Journal of English Education), 4(2), 111-119. doi:10.15408/ijee.v4i2.8538. 


\section{INTRODUCTION}

Robust debate over the last few decades as to the place of explicit grammar instruction in teaching a second language, either in an ESL (English as a Second Language) or EFL (English as a Foreign Language) setting, seems to have settled on the position that "there is now convincing indirect and direct evidence to support the teaching of grammar" (Ellis, 2006, p. 87). Nevertheless the questions of what grammatical structures to teach, and especially how to teach them remain controversial (Boroujeni, 2012; Ellis, 2006; Mart, 2013).

In Indonesia, grammar rules are generally taught deductively (Ana \& Ratminingsih, 2012; Arifin, 2016; Rusdi \& Hafid, 2016; Wiwoho, 2016; Yunita, 2016). Learners expect to be told the rule before examining its application. Unsurprisingly, some rules are more difficult to teach than others. One that provides a significant challenge to teaching is the second conditional, or the unreal/hypothetical conditional, as it is generally referred to in grammar books (Parrott, 2000; Swan, 2005).

Given that a deductive or 'ruledriven' approach for teaching the second conditional has met with little learning success in the teaching experience of the author, this study examined an attempt to consciously apply an inductive approach to teaching this challenging grammatical structure. Deriving the grammar rule from a richer communicative context could potentially deliver superior learning outcomes.

Learners can achieve an understanding of a grammar rule basically through two ways: a deductive or rule-driven path and an inductive, or rule-discovery path (Thornbury, 1999). The former approach continues to be largely used when teaching English in an EFL context. Typically, in deductive teaching "a grammatical structure is presented initially and then practised in one way or another" (Ellis, 2006, p. 97), an approach that works well for some students and some language points (Harmer, 2007).

In an inductive approach, on the other hand, the learner seeks to derive an understanding of the grammar patterns by studying examples of language. The student learns 'experientially', and, through discovery, is asked to do the work normally done by the teacher or other resources such a grammar texts (Harmer, 2007). An advantage of this approach is that it leads to more powerful learning. Students have to make a greater cognitive effort to uncover the grammar structures themselves, and in that 
process have to activate their existing mental structures to accommodate the new (Harmer, 2007; Thornbury, 1999).

Both deductive and inductive approaches have their advantages and disadvantages. Either may be the more effective teaching approach at a particular time depending on factors including the nature of the rule to be taught, the learners' level of language knowledge and skill, and the cultural pedagogic expectations of the learners (Harmer, 2015; Mallia, 2014; Thornbury, 1999). The inductive approach particularly favours students who "already have a certain amount of language available to them" (Harmer, 2007, p. 82), and who enjoy learning through pattern-recognition and problem-solving activities (Thornbury, 1999) and are therefore likely to be skilled in grammatical analysis. For these reasons, it may be that more complex rules better lend themselves to being taught inductively (Ellis, 2006).

While the research on the relative benefits of the two approaches is inconclusive (Thornbury, 1999; Ellis, 2006), and "the theoretical and practical views on the role of grammar in language teaching are still changing "...there seems to be an emphasis on using communicative and inductive approaches to assist learners to tap into their growing competence" (Joyce \& Burns, 1999, p. 49). This general trend, together with the lack of success in teaching some grammar rules deductively, and the language competence of the student group, prompted the interest in undertaking this research.

In considering which grammar rule to teach, Ellis (2006) suggests that, in the absence of any definitive research informing the choice, a reasonable place to begin is to focus on the errors known to be produced by learners. One such example is the English conditional which is recognised as a particularly difficult grammar rule to teach and learn. In one study, ESL teachers identified the conditional as representing their $5^{\text {th }}$ most serious teaching problem (Celce-Murcia \& Larsen-Freeman, 1999). Typically, learners, including native English speakers, have difficulty grasping the more complex syntax of these twoclause sentences, and the subtlety of their meaning and use (Celce-Murcia \& Larsen-Freeman, 1999; Parrott, 2000). This is even more so the case for Indonesian EFL students because in Indonesian there is only the one conditional form.

The purpose of this study was therefore to teach the conditional, more particularly the second or unreal/hypothetical conditional, to 
assess whether an inductive approach would enable students to gain a better grasp of the form, function and meaning of the grammar rule. Essentially, the study takes a 'what happens if' approach (Baumfield, Hall \& Wall, 2008).

\section{METHOD}

Ten English teachers, most of whom had considerable EFL teaching experience, participated in this study. The benefit of having such experienced subjects was that they would be in a position to provide insightful and critical feedback based on their relevant teaching experience as well as their engagement as 'students'. Farrell (2001) notes that peer feedback emerging from critical friendships is characterised by the collaboration of colleagues with the aim of enhancing the quality of teaching and learning as well as improving the reflective abilities of the researcher. This critical friendship "can give voice to a teacher's thinking, while at the same time being heard in a sympathetic but constructively critical way" (Hatton \& Smith as cited in Farrell, 2001, p. 369). Besides, peer feedback could also cover the area of critical thinking as well as supporting learner to be independent with the autonomy provided by the teachers
(Bijami, Kashef \& Nejad, 2013; Zhao, 2014).

Two teaching sessions, each 25 minutes, were presented three weeks apart to the same group of subjects. Lesson plans are at Appendix A, with the first session labelled A1 and the second, revised session, labelled A2. Both sessions were conducted by the same teacher.

Following each session, the participants were asked to complete a brief questionnaire (Appendices B1 \& B2 ) providing both qualitative (open questions) and quantitative (their views in response to statements, on a scale of 1-5) feedback. In addition, after the first session, participants remained for 20 minutes to elaborate on their written responses.

\section{FINDINGS AND DISCUSSION}

The summaries for the qualitative data reflect the main themes identified by participants. Single statements have not been included if they showed no pattern or related only to general teaching techniques (e.g., 'improve board writing').

In summary, the overall feedback (Q11) indicated that both sessions were assessed by the participants as about equally successful, with slightly fewer 'extreme' assessments (ie fewer "very 
strongly' and 'disagree') in response to the second lesson. This was contrary to expectations, given that the second session took into account participants' feedback from the first.

Participants identified the strengths of the first session as the type of activities, the opportunity for their active participation including group work, and the authentic material. They recommended improvements in the clarity of explanations (including the introductory activity), more opportunities to practice, and a clearer demonstration of the distinction between the form, meaning and use of the first and second conditionals. This was supported by their ratings on questions 1-11 of the feedback form. Most participants seemed, at best, ambivalent as to whether that the grammar rule had been clearly developed (Q2), although curiously most agreed that they had been able to discover the grammar rule for themselves (Q1) and that the rule and its application were clearly understood (Qs 3 \& 4), perhaps a reflection of their prior grammar knowledge. Consistent with the qualitative feedback, most agreed that the sequencing of activities was appropriate (Q5), that the activities were engaging $(\mathrm{Q} 6)$ and relevant $(\mathrm{Q} 7)$, and that the lesson was memorable (Q10).
Because the inductive approach provides a framework for teaching rather than a prescriptive formula, its proponents can and do differ "as to how best this input should be selected and organised...[and] how and how often the teacher should intervene" (Thornbury, 1999, p. 49). The feedback from this initial session therefore provided a basis for revising the input, activities and their sequencing for the second presentation three weeks later.

As a consequence of participants' feedback and the author's observations, specific changes to the session included replacing the introductory newspaper excerpt with a constructed dialogue to provide controlled modelling of the second conditional, eliminating the introductory review of the first conditional as it seemed to cause confusion, and introducing the puppet story to give greater attention to the meaning and use of the second conditional. These changes directly addressed feedback from the first presentation, and were intended to provide more content from which to generate the second conditional grammar pattern to be elicited later in the session.

Following the second session, the overall feedback was that while half the participants 'agreed' (but not 'strongly') that the lesson was 
successful, about half indicated ambivalence; they neither agreed nor disagreed. This was a weaker result than that from the first presentation when eight of ten had at least 'agreed' (and two had 'strongly agreed') that the session had been successful. Nevertheless, in their qualitative feedback participants highlighted as strengths that the lesson was interesting and memorable (with three singling out the new introductory activity [dialogue script] in particular), the level of lively student participation and the relaxed environment. This was supported by the quantitative feedback that showed that eight participants 'strongly agreed' that the activities were engaging (Q6), and eight 'agreed' (including three 'strongly') that the lesson was memorable (Q10), particularly following the inclusion of the puppet story.

However, in terms of weaknesses the participants reported that the rule was not explicit enough either in elicitation or presentation, and that its form, function and use had not been sufficiently contrasted with the first conditional, an impression supported in general by the quantitative feedback on Qs 1-4. Essentially half the class expressed ambivalence as to whether the grammar rule was clearly developed (Q2), clearly understood (Q3) and could clearly be applied (Q4), while the other half 'agreed' that it had been. Significantly, unlike after the first session, no-one 'strongly agreed' that these teaching goals had been achieved. Furthermore, while the introduction of the puppet story at the end of the second presentation was considered a noteworthy improvement on the previous session, participants reported that better use could have been made of it to contrast the meanings of the two conditionals. Finally, participants identified the main improvements in the second presentation as the inclusion of the puppet story, and the better organisation of activities.

The project had the benefit of experienced EFL teachers as participants, most of whom teach grammar deductively. They acted as "sceptical colleague[s]" (Baumfield et al., 2008, p. 21), and indeed provided critical and constructive comment, expressing a distinct preference for clearer rule presentation. Given that a significant factor in the success of applying a rule-discovery approach is the learners' preferred learning strategies (Chamot, 1987; Harmer, 2015; Richards \& Lockhart, 1996), it is interesting to reflect on the extent to which the participants' own preferences may have coloured their assessment of the 'success' of this session. Students' different learning styles will always be a consideration. However "if we are 
aware of this and act accordingly, then there is a good chance that most of the class will be engaged with the learning process most of the time" (Harmer, 2015, p. 50).

The author agreed with the feedback that the structure of the lesson could be improved, particularly in respect of the number of activities attempted and their sequencing. Several participants remarked that some activities, while interesting and enjoyable, were not exploited sufficiently for the purposes of the grammar point, and then ultimately seemed less meaningful and even confusing. The author similarly observed that in the attempt to provide variety, maintain engagement, and finish the session on time, the number of activities had been ambitious, leaving insufficient time for deeper elicitation of the grammar pattern, and for practice. Students need to be allowed the time and opportunities to gain insight and generalise about the use of patterns, after which the teacher's development of the explicit rule statement from these insights, emerges more meaningfully and honestly (Thornbury, 1999). Even within the 25 minute limit, more recycling of grammar could have been built into the session allowing "for the kind of gradual acquisition of grammar that is compatible with what is known about interlanguage development" (Ellis, 2006, p. 92).

Again both the author and participants agreed that greater contrast between the first and second conditional could have helped clarify the form, meaning and use of this subtle grammar rule. While Ellis (2006) suggests that complex grammar rules generally lend themselves more readily to elicitation, it seemed that, in this case, more explicit instruction of the pattern form would have been beneficial, possibly because of the participants' expectations (Ellis, 2002).

Finally, perhaps the choice of the second conditional for this lesson was too ambitious. Several authors note the difficulties learners have with conditionals (Celce-Murcia \& LarsenFreeman, 1999; Parrott, 2000), and the investigation of the use of 'if' clauses in spoken corpora data reveals more than 30 patterns in use, of which the three 'traditional' conditional patterns accounted for fewer than half of these. Moreover, despite the grammatical irregularity of these patterns, the meanings were apparently perfectly understood by the participants (O'Keeffe, McCarthy \& Carter, 2007). This begs the bigger question of how much effort in any case, a teacher should put into teaching the fine 
distinctions of the three traditional conditional forms.

\section{CONCLUSION AND SUGGESTION}

This research study provided an opportunity to apply a different teaching approach to a known grammar challenge within in a controlled environment, to gather data, and to "achieve reflection that is both sufficiently embedded in the day-today needs of practice and sufficiently distanced from the 'taken for granted' to be a lever for change" (Baumfield et al., 2008, p. 63). Certainly the inductive approach had its strengths in terms of creating interest and engaging participants; however it was also clear that eliciting a grammar rule requires careful preparation and sequencing of activities, takes time both in preparation and for participant activities, and is likely to work better for most participants if attention is also given to form as well as function and meaning.

\section{REFERENCES}

Ana, I. K. T. A., \& Ratminingsih, N. M. (2012). Teaching English tenses to EFL learners: Deductive or inductive? International Journal for Cross-Disciplinary Subjects in Education (IJCDSE), 2(2), 998-1004.
Arifin, S. (2016). Deductive and inductive methods in teaching tenses. Journal of ELT Research, 1(1), 73-89.

Baumfield, V., Hall, E., \& Wall, K. (2008). Action research in the classroom. Los Angeles: Sage.

Bijami, M., Kashef, S. H., Nejad, M. S. (2013). Peer feedback in learning English writing: Advantages and disadvantages. Journal of Studies in Education, 3(4), 91-97.

Boroujeni, F. A. (2012). Investigating controversies in teaching Grammar: A case for the Iranian High School Students. Theory and Practice in Language Studies, 2(8), 1570-1575.

Brown, J. D. (1988). Understanding research in second language learning: A teacher's guide to statistics and research design. Cambridge: Cambridge University Press.

Celce-Murcia, M., \& Larsen-Freeman, D. (1999). The grammar book: An ESL/EFL teacher's course ( $2^{\text {nd }}$ ed.). Boston: Heinle \& Heinle.

Ellis, R (2002). The place of grammar instruction in the second/foreign language curriculum. In E.Hinkel \& S. Fotos (Eds.), New perspectives on grammar teaching in second language classrooms (pp. 17-34). New Jersey: Erlbaum.

Ellis, R. (2006). Current issues in the teaching of grammar: An SLA perspective. In TESOL Quarterly, 40, $1,83-108$.

Farrell, T. (2001). Critical friendship: Colleagues helping each other develop. ELT Journal, 55, 4, 368 - 374. 
Harmer, J. (2015). The practice of English language teaching (5 $5^{\text {th }}$ ed.). Essex: Pearson Education.

Harmer, J. (2007). How to teach English. Essex: Pearson Education.

Joyce, H., \& Burns, A. (1999). Focus on grammar. Sydney: Macquarie University

Mallia, J. G. (2014). Inductive and deductive approaches to teaching english grammar. Arab World English Journal, 5(2), 221-235.

Mart, C. T. (2013). Teaching grammar in context: Why and how? Theory and Practice in Language Studies, 3(1), 124129.

O'Keeffe, A., McCarthy, M., \& Carter, R. (2007). From corpus to classroom: Language use and language teaching. Cambridge: Cambridge University Press.

Parrott, M. (2000). Grammar for English language teachers. Cambridge: Cambridge University Press.

Richards, J. C., \& Farrell, T. S. C. (2006). Professional development for language teachers: Strategies for teacher learning. Cambridge: Cambridge Language Education.

Richards, J. C., \& Lockhart, C. (1996). Reflective teaching in second language classrooms. Cambridge: Cambridge University Press.
Rusdi, M., \& Hafid, A. G. (2016). The effectiveness of using crossing formulas of tenses table in learning English 16 tenses at XII grade students of MA Madani Alauddin Paopao in Academic Year of 2015/2016. ETERNAL, 2(1), 96-109.

Swan, M. (2005). Practical English usage (3 ${ }^{\text {rd }}$ ed.). Oxford: Oxford University Press.

Thornbury, S. (1999). How to teach Grammar. Essex: Pearson.

Wiwoho, A. N. (2017). Grammar teaching approaches for adult EFL learners: An Indonesian perspective. IAFOR Conference Proceedings, retrieved from http:/ / 25qt511nswfi49iayd31ch80wpengine.netdna-ssl.com/wpcontent/uploads/papers/acss2017/ ACSS2017_36878.pdf.

Yunita, W. (2016). Best practice in teaching English Grammar to university students: deductive, inductive, or combination of both? Proceedings of the Fourth International Seminar onEnglish Language and Teaching (ISELT-4), 435-443.

Zhao, H. (2014). Investigating teachersupported peer assessment for EFL writing. ELT Journal, 68(2), 155-168. 